\title{
Family with clots: antithrombin deficiency
}

\author{
Samer Al Hadidi, ${ }^{1}$ Kristi Wu, ${ }^{1}$ Ahmed Aburahma, ${ }^{2}$ Zain Alamarat $^{3}$
}

${ }^{1}$ Department of Internal Medicine, Michigan State University, Flint, Michigan, USA ${ }^{2}$ Department of Internal Medicine, Hurley Medical Center, Flint, Michigan, USA ${ }^{3}$ Department of Pediatrics, Hurley Medical Center, Flint, Michigan, USA

\section{Correspondence to Dr Samer Al Hadidi, salhadi1@hurleymc.com}

Accepted 4 August 2017
CrossMark

To cite: Al Hadidi S, Wu K, Aburahma A, et al. BMJ Case Rep Published Online First: [please include Day Month Year]. doi:10.1136/bcr-2017221556

\section{DESCRIPTION}

A 44-year-old African-American woman presented to the emergency department with chest pain and shortness of breath of 12 hours prior to presentation. Her medical history includes antithrombin deficiency, recurrent deep venous thrombosis (DVT), recurrent pulmonary emboli, poorly controlled hypertension, diabetes mellitus, asthma, inferior vena cava filter placement, pulmonary hypertension and bipolar disorder. Her surgical history includes bilateral pulmonary thromboendarterectomy 3 months prior to presentation. She reported non-compliance to Coumadin. She smokes half a pack per day for the last 25 years. Family history is positive for multiple early deaths secondary to thromboembolic complications.

Physical examination showed tachycardia with heart rate of 105 beats per minute. Chest examination was significant for bilateral rales at the lung bases. ECG showed sinus tachycardia, cardiac troponins were negative and international normalised ratio was 1.08. Venous duplex of the lower extremities showed chronic DVT.

Chest CT scan with contrast showed an occlusion of the left brachiocephalic vein surrounding a Mediport catheter with a large thrombus

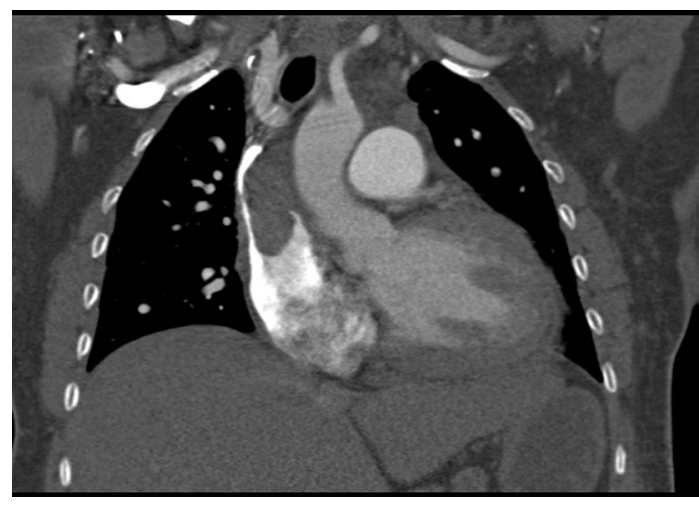

Figure $1 \mathrm{CT}$ of the chest with contrast showing occlusion of the left brachiocephalic vein surrounding the Mediport catheter with large thrombus seen within the superior vena cava hanging into the superior vena cava and part of the right atrium. The thrombus is measuring $4.7 \times 2.1 \mathrm{~cm}$ in size. extending into the superior vena cava and right atrium (figure 1). The superior vena cava was not completely occluded. CT also showed right lower lobe segmental pulmonary arterial thromboembolism. Patient was advised to stay on lifelong enoxaparin injections $1.5 \mathrm{mg} / \mathrm{kg}$ and was referred to a tertiary cardiac surgery centre for surgical intervention. She underwent clot removal. She was maintained on enoxaparin with no further thromboembolic complications for 2 years follow-up.

Antithrombin is a potent inhibitor of thrombin and other coagulation serine proteases. ${ }^{1}$ Antithrombin deficiency is a hereditary thrombophilia which is inherited as autosomal dominant with variable penetrance. ${ }^{1}$ Antithrombin deficiency lifetime probability of developing thrombosis was 8.1 times higher than those without the defect. ${ }^{2}$ Long-term anticoagulation is indicated for high-risk patients with recurrent thromboembolic episodes. ${ }^{3}$

\section{Learning points}

- Patients with antithrombin deficiency are at higher risk of thromboembolic episodes.

- Identifying patients with antithrombin deficiency is crucial for prevention and treatment of thromboembolic complications.

Contributors KW, AA and ZA edited the case and reviewed the related literature. SAH wrote the case, reviewed the related literature and accepted the final version.

Competing interests None declared.

\section{Patient consent Obtained.}

Provenance and peer review Not commissioned; externally peer reviewed.

(C) BMJ Publishing Group Ltd (unless otherwise stated in the text of the article) 2017. All rights reserved. No commercial use is permitted unless otherwise expressly granted.

\section{REFERENCES}

1 Khor B, Van Cott EM. Laboratory tests for antithrombin deficiency. Am J Hematol 2010;85:947-50.

2 Martinelli I, Mannucci PM, De Stefano V, et al. Different risks of thrombosis in four coagulation defects associated with inherited thrombophilia: a study of 150 families. Blood 1998;92:2353-8.

3 Schulman S, Granqvist S, Holmström M, et al. The duration of oral anticoagulant therapy after a second episode of venous thromboembolism. The Duration of Anticoagulation Trial Study Group. N Engl J Med 1997;336:393. 
Copyright 2017 BMJ Publishing Group. All rights reserved. For permission to reuse any of this content visit http://group.bmj.com/group/rights-licensing/permissions.

BMJ Case Report Fellows may re-use this article for personal use and teaching without any further permission.

Become a Fellow of BMJ Case Reports today and you can:

- Submit as many cases as you like

- Enjoy fast sympathetic peer review and rapid publication of accepted articles

Access all the published articles

- Re-use any of the published material for personal use and teaching without further permission

For information on Institutional Fellowships contact consortiasales@bmjgroup.com

Visit casereports.bmj.com for more articles like this and to become a Fellow 